Article

\title{
The Transnationalization of the Akan Religion: Religion and Identity among the U.S. African American Community
}

\section{Pauline Guedj}

Department of Anthropology, Université Lyon 2, 5 av. Pierre Mendès-France, 69676 Bron Cedex, France; E-Mail: pauline.guedj@univ-lyon2.fr; Tel.: +33-4-78-77-31-73

Academic Editor: Peter I. Kaufman

Received: 16 September 2014 / Accepted: 19 December 2014 / Published: 8 January 2015

\begin{abstract}
In 1965, Gus Dinizulu, an African American percussionist, traveled to Ghana with the dance company he was leading. There, he took the trip as an opportunity to explore his African roots and met Nana Oparebea, the Ghanaian chief-priestess of the Akonedi Shrine, one of the most famous shrine houses north of Accra. At the Akonedi Shrine, Nana Oparebea performed for Dinizulu a divination, during which she explained that his enslaved ancestors were parts of the Akan people of Ghana and gave him the mission to search for other African Americans who, like him, were of Ghanaian ancestries. She also offered him a set of altars, containing the spiritual forces of the deities revered in the Akonedi Shrine and asked him to import in the United States what was then labelled the Akan religion. Based on research led both in Ghana and in the United States, the aim of this paper will be to describe the process of diffusion, importation, transnationalization and indigenization of the Akan religion between West Africa and the East Coast of the United States. Focusing on ethnographic data, we will argue that this process can only be understood if it is placed in the context of African American identity formations. Therefore, we will show how in the context of globalization, religion and identity constructions are walking hand-in-hand, creating new discourses on hybridity and authenticity.
\end{abstract}

Keywords: African American religions; Akan; Pan-Africanism; slavery; transnationalization; globalization 


\section{Introduction}

In the second half of the 1960s, in the United States, African American nationalism entered a new stage of its history. Facing ongoing inequalities despite the hopes produced by the Civil Rights Movement, numbers of African Americans began disassociating themselves with internal policies struggles and included their fights in a more international and Pan-African setting. At the same time, de-colonization in Africa, the rising of Ghana in 1957, as well as the creation of 17 independent African nations in 1960 had a profound influence among African American activists [1]. In that context, African peoples became new models that could inspire African American activists in their fight against oppression and discrimination, while Africa assumed a new crucial position in Black nationalism's symbolic representations.

Until 1965, the African continent largely had been ignored by leaders of the Nation of Islam-the major Black nationalist organization of the time [2]. However, soon afterward, similar efforts and philosophies originating from the African continent made groundbreaking appearances in the discourses of various American Black Power movements. Specialized literature tends to oppose two types of Black power struggles. On the one hand, revolutionary movements fought for the complete redefinition of racial hierarchies in the United States, sometimes advocating armed struggle to lead a complete revolution. For these freedom fighters (Stokely Carmichael, Elridge Cleaver, Bobby Seale, Huey P. Newton), Black America was seen as an internal colony inside of the United States territory [3]. In their view, this internal colony had to lead a violent fight towards de-colonization, whose principles could be found in the actions and writings of such African leaders as Kwame Nkrumah, Amílcar Cabral and Sékou Touré. The most famous organization of that first category was the Black Panther Party. Founded in 1966 in Oakland, California by Bobby Seale and Huey P. Newton, the Party doubled its self-defense activities with various social programs in urban Black neighborhoods.

On the other hand, African American cultural nationalists were the proponents of what they referred to as “cultural conversion”. Instead of advocating immediate revolution, they claimed, either as an end or as an intermediate stage in their political program, the restoration of Black Americans' cultural integrity and a politics of roots recovering. For Amiri Baraka, a major African American writer who was at one time a proponent of cultural nationalism, African Americans had to separate themselves "mentally" and "psychologically" from White people. In that regard, he posited that Black nationalism did not need to be constructed around a discourse of political separatism anymore, but could use culture as a weapon that would enable African Americans to live according to their true selves. African Americans had been pushed down into compliance by slavery and colonialism. It was now time for them to rise again and to create an integral community, conscious of its roots and cultural specificities and that does not bow to White supremacy anymore.

For African American cultural nationalists, religion and spirituality became unavoidable tools in their attempt to recover their ancestral roots. In most of their writings, Africa was described as an inherently spiritual land whose existence is determined by beliefs in spirituals deities and forces [4]. Therefore, if any African Americans want to reconnect with their roots, they have to start with religion and try to become the spiritual individuals they believe they once were. That idea of a mainly spiritual and religious Africa is grounded in an imaginary reconstruction of the African continent based on African American expectations, projections and political ideologies. In that regard, Africa can be 
understood as an often fantasied Motherland, whose descendants are not necessarily physically connected to.

Between 1965 and 1975, a few religious movements were created to offer African Americans direction in their attempt to recover what they thought of as their spiritual roots. Most of these religious groups were born in New York City. In early 1960s Harlem, artist-activist Walter King, then renamed Oseijeman Adefunmi, created a place of worship called the Yoruba Temple. Based on an effort to re-Africanize Cuban Santería, an Afro-Catholic religion that had been present in the neighborhood since the end of the 1950s, the movement claimed the Yoruba ancestries of African Americans and taught them how to worship the deities revered by the Yoruba people of Nigeria: the orisha [5-7].

In 1973, another group was created in Harlem and in Brooklyn by Ra Un Nefer Amen I. Entitled the Ausar Auset Society, the group based its beliefs on a series of writings on Egyptian spirituality. The group leader, as with many Afrocentric scholars later, considered Egypt to hold in its culture the ultimate essence of African traditions and spirituality [8]. Therefore, going back to Egypt, or to Kemet, as Ra Un Nefer Amen I would put it, was seen as the most authentic experience in re-Africanization ${ }^{1}$.

Finally, the borough of Queens saw the creation of a group often referred to as the Akan movement. Built upon transnational networks forged between the East Coast of the United States and Ghana, the movement put forth the Ghanaian and Akan ancestral identities of African Americans, attempted to reproduce the religion coming from that region of Africa, often modifying and redefining it.

Based on research conducted among the Akan movement between 2002 and 2008, the aim of this paper will be to return to the history and state of the movement during that time. We will analyze here how, thanks to the creation of global and transnational networks, members of that group have been able to import an African religion, to reappropriate it and to adapt it to the realities of their religious field. This paper will show how, in the context of globalization, religion and identity constructions are walking hand-in-hand, creating new discourses on hybridity and authenticity².

\section{The Birth of the Akan Movement}

The Akan movement was born in 1965, when Gus Dinizulu, an African American percussionist and leader of a New York City dance company, left the United States to take his group on a West African tour. Long before his departure, Dinizulu had already begun attempting to reconnect African Americans with their African ancestries. Indeed, by 1947, he had founded The Ghanas, a cultural association that organized dance classes and exhibitions on Africa at the Harlem Young Men's Christian Association. A few years later, he and his friend, Walter King, future king of the American Yoruba, created the spiritual order of Damballah Hwedo, whose practices had been borrowed from various African or African-based religions, such as the Yoruba, the Akan and Haitian vodu. In the

1 The expression re-Africanization has been used by various anthropologists to describe the attempt led by political and religious activists in the Black diaspora to enhance what they considered as the African essence of their cultural practices. For an analysis of re-Africanization processes in Latin America, see [9,10]. For a study of that issue in the United States, see [11-13].

2 This paper expands on a set of chapters published in France between 2005 and 2009. It is the first publication of that research in English. 
early 1960s, Dinizulu founded his African dance company, The Dinizulu African Dancers, Singers and Drummers, which immediately became popular in various parts of the East Coast. Finally, in 1965, following a year of touring in the United States, Dinizulu and his dancers flew to West Africa and took part in a series of cultural events. The tour traveled through Nigeria and the Ivory Coast, but it was in Ghana that the leader first met the woman who was to become his African "alter ego".

In Accra, Dinizulu conducted research on many West African traditions and the Akan in particular. To do so, he studied at the University of Ghana, Legon's library, and chose Amantefio, a Ghanaian man who had aided him in discovering the region's many sites and points of interest, to be his guide. Amantefio taught Dinizulu about the Akonedi shrine, a very popular Ghanaian shrine, located in the city of Larteh Kubease in Akwapem. The shrine owed its popularity to its chief priestess, Nana Ekua Oparebea, a woman who had been appointed by Kwame Nkrumah, prime minister of the country, to lead the Ghana Psychic and Traditional Healing Association ${ }^{3}$, a national association that assembled the various traditional healers practicing in the country.

Inspired by what he had learned from Amantefio, Dinizulu left Accra for Larteh Kubease. There, Nana Oparebea not only opened the doors of her shrine and gave Dinizulu his first introduction to the beliefs and rituals found in the "House of Akonedi", but also significantly offered him a divination or reading during which she believed she would be able to provide him with details about the identity of his African ancestors. Dinizulu gave his consent to the process, the divination, which, for many American Akan, is heralded as the movement's founding act.

Both the African American practitioners and the Ghanaian priests agree that during that divination, Nana Ekua Oparebea explained to Dinizulu that she had been given a mission by the deities to find her “children in America”. Oparebea was aware that many Akan had been brought to America as slaves, and so she believed that sending the gods to their descendants abroad was her divine path. Dinizulu's visit thus served as the absolute proof of the legitimacy of her mission. Oparebea revealed to Dinizulu the identity of his ancestors and explained that the clan to which he belonged was in fact her own father's clan. She named him Nana Yao Opare Dinizulu ${ }^{4}$, a new name that would celebrate the memory of his ancestors, and made him the Omanhene, "Chief of the Akan of America". Dinizulu was also considered as a caretaker of the many abosom, or deities, of the Akonedi shrine and was given a series of altars containing the deities' spiritual forces.

For Nana Oparebea, this connection created between Dinizulu and herself and, more precisely, between the African American musicians and dancers hosted in Larteh and the Akan population, has to be analyzed in the political context of Ghana's Akwapem region. In fact, in a region that has long been the scene of altercations between its Guan population and the Akan people [15], the Akonedi shrine has been the place of similar tensions. Whereas the shrine was known in the 1950s as a predominantly

3 When Kwame Nkrumah was nominated Prime Minister of Ghana in 1952, he insisted immediately on the necessity of creating a policy promoting the various traditions and medical techniques represented in the country. For him, this effort of promoting Ghanaian traditions would emphasize the local specificities of Ghana in the international scene, as well as help in the formation of links between the Nation and the different colonies en route for emancipation. In harmony with this political position, Nana Oparebea and her Akonedi Shrine had then become two symbols of these African traditions that had to be preserved and exported. About the Ghana Psychic and Traditional Healing Association, see [14].

4 Here, Nana is the title associated with an elder in any Akan societies. Yao refers to the day on which Dinizulu was born, a Thursday, and Opare to the clan to which Oparebea connected him. 
Guan place of worship, whose major priest or osofo was himself a Guan man, Nana Oparebea has attempted to add new deities to the shrine and to "akanize" its practices. Symbolically including Dinizulu into her on lineage was then not only a way to interfere within the local political context but also an attempt to extend the Akan networks she was building locally at the international level. Today, in the United States, practitioners of the Akan religion are, for most of them, not claiming any connections to Guan deities and concentrate their identity politics towards a recreation of an ancestral Akan identity.

Upon his return to America, Dinizulu became a "missionary" of the Akonedi shrine. He spread the word of what was called the "Akan" religion and tradition and announced his enstoolment as a chief in Ghana. In 1968, he opened the Bosum Dzemawodzi ${ }^{5}$, the first Akan shrine house in America, and The Aims of the Modzawe ${ }^{6}$, an African cultural center then located in Long Island City, Queens, New York. The Bosum Dzemawodzi hosted the first Akan ceremonies performed by African Americans and offered training in the religion for those who received the call to become priests. Meanwhile, the Aims of the Modzawe was used as a rehearsal space for the Dinizulu African Dancers, Singers and Drummers and as a center where people could learn about African dance, music, traditions, languages and history.

While Dinizulu was establishing the Akan movement in New York, Nana Ekua Oparebea was hosting a growing number of African Americans on trips to West Africa. Between 1968 and 1995, the year when she died, Nana Oparebea trained a number of African Americans in the priesthood and performed dozens of graduation ceremonies for her "American children”. Many of the Americans she hosted in Ghana, Caletha Nock and Doctor Brown, in particular, became extremely active within the movement in the United States. Caletha Nock, renamed Nana Korantemaa Ayeboafo, first traveled to Larteh with her dance company, the Arthur Hall Afro-American Dance Ensemble. She spent seven years at the Akonedi shrine and was later named by Nana Oparebea as a leading member of the Akan movement in Philadelphia. Doctor Brown, ex-linguist in Dinizulu's Bosum Dzemawodzi, was initiated into the priesthood in 1978 and created with Nana Oparebea the major Akan shrine house in Washington, D.C.

To evaluate the traditional accuracy of her trainees' practices, to teach them different rituals and to help them to build shrines for their deities, Nana Oparebea visited the United States nine times, each visit lasting approximately three months. She also sent three of her Ghanaian "godchildren” to America so that they could act as mediators between her and the African Americans.

\section{Becoming Akan}

Today, a few thousand African Americans practice the Akan religion, most of whom live in New York City, Philadelphia, Washington, D.C. and Baltimore. In New York City, the Bosum Dzemawodzi relocated to another neighborhood in Queens, Jamaica. Until 2013, it was led by Nana Kimati Dinizulu II, succeeding his father Yao after his death in 1993. Like his father, Nana Kimati, who passed last year, was called the Omanhene, "chief of the Akan of America”. He was surrounded by a court of lawyers, linguists, treasurers and a queen mother.

5 The words bosum and dzemawodzi both mean deities. The first one is in Twi, the second in Ga.

6 The word modzawe indicates in Ga the place where the men of a village meet to talk and discuss issues. 
New York is also the location of a number of other temples or shrine houses that first appeared in the 1970s and 1980s. Onipa Abusia ${ }^{7}$, created by two of the nine wives with whom Nana Yao Opare Dinizulu lived during his life ${ }^{8}$, is still active in Queens. Additionally, in Brooklyn, the Nana Oparebea shrine was created in 2002 by Nana Nsia Dennis, a Ghanaian priestess who had been sent by Nana Oparebea to America at the end of the 1970s. Today, Nana Nsia often travels between Ghana and the United States.

In Philadelphia, the Akan religion is practiced in a few shrine houses. While I was conducting my research, two of them were particularly active. The first, the Asona Aberade Shrine, is the oldest in Pennsylvania. It was run by Nana Korantemaa Ayeboafo, an okomfo who, in 2003, was enstooled in Larteh, Ghana, as Okomohene, chief priest of the "Akan of America”. Nana Korantemaa spent part of each year in Larteh, resulting in her election by the elders of the Akonedi shrine to act as their representative in the United States. Many American Akan, however, refused her status and denounced her as an imposture. In doing so, they were knowingly disregarding the directives of their Ghanaian mother shrine. The second Philadelphia shrine house, the Adade Kofi Bosomfie Sankofa, was led by Nana Baakan Agyiriwah, who was trained in the priesthood first by Nana Korantemaa and then by Nana Nsia. Feeling very close to the woman she called her godmother, Nana Baakan visited Brooklyn's Nana Oparebea shrine frequently and often asked Nana Nsia to assist her in her practice of the rituals and ceremonies.

Finally, a number of shrine houses in Washington, D.C., also practice the Akan religion. One of the most frequented, Nana Kyerewaa's Asomdwee Fie Shrine of the Abosom and Nsamanfo Inc., is closely tied with the Bosum Dzemawodzi. Finally, while I as doing the research, Washington was also home to a branch of New York's Onipa Abusia and significantly to the Asuo Gyebi shrine, which was founded by Nana Kwabena Brown and Nana Oparebea in the early 1970s.

While I was conducting my research, conflicts and competitions between the different shrine houses were very common. Typically, the members of a shrine house formed close bonds with their initiators often to the detriment of the other priests with whom they were not as closely connected. For example, whereas Nana Nsia's godchildren were united and tended to collaborate with the godchildren of Nana Kwabena Brown, their connection with the members of Dinizulu's shrine house was sporadic.

The practitioners of the Akan religion frequently traveled between New York City, Philadelphia and Washington, D.C., both to assist their own religious families in the organization of rituals and to visit sympathizing shrine houses. Geography and long distances seemed not to be relevant concerns; it was more preferable for American Akan practitioners to attend ceremonies arranged by non-local shrine houses closely connected to their godmothers or fathers, than it was to seek out unrelated shrine houses that were more conveniently located.

Each shrine house is led by a major priest or Nana who is in charge of organizing the public ceremonies, feeding the altars and supervising the various private rituals, such as the spiritual baths

7 Onipa Abusia is said to mean in Twi "happy family".

8 Some Akan shrine houses are assembling practitioners who consider polygamy as a way for them to discover and reproduce their African self. In the United States, the Akan shrine houses are then divided between those who legitmize the practice of polygamy, generally led by male okomfo, and those who condemn it. 
that the practitioners are required to take at different stages of their lives ${ }^{9}$. The Nanas are assisted by their godchildren, including the graduated priests, known as the akomfo, who recently underwent their three-year period of training, and the current trainees known as the akomfowa. In addition, many other people also participate in the public rituals held in the houses, sometimes consulting with the Nanas during the readings or divinations that they perform three days a week while sitting in front of the altars of their shrine rooms.

When a sympathizer joins an Akan shrine house, he submits himself to a series of rituals aimed at incorporating him into the group. At the conclusion of the process, he is deemed a legitimate inheritor of the Akan of Ghana and is considered a practitioner worshipping, in his own right, the religion of his ancestors. The first of these rituals consists of giving to the future Akan a shrine name ${ }^{10}$. This name is determined by the Nana during a reading or divination that is held in front of the shrines. In general, the American Akan receives a patronymic name corresponding to the day of the week in which he was born, Kodjo for a man born on Monday or Abena for a woman born on Tuesday.

This patronymic name is followed by another designation intended to welcome the worshipper into the clan structure of Larteh Kubease and to integrate him within the Akan "family"11 of Nana Ekua Oparebea. Agyiriwah, Antesewaa, Tacheampong and Oparebea have become extremely popular names for Akan practitioners and are frequently used to commemorate the ancestors said to have chosen particular worshipers as the caretakers of their own "families" and clans. Occasionally, the naming ceremony also provides the American Akan with details about his or her origins and with a list of taboos associated with the clan to which his enslaved ancestors supposedly belonged.

Following the shrine name ritual and after receiving a series of spiritual baths aimed at purifying him and preparing his contacts with the deities, the practitioner receives a scarification, which is performed on his or her right arm and which becomes the paramount symbol of his belonging to the Akan group. The scar, made in the shape of a straight line from which a series of branches deviates, is accomplished in Larteh during the ceremony enstooling a new priest. It symbolizes the shift in the practitioner's life from a simple believer to an okomfo. Renamed "tree", the scarification carries a different meaning in the United States. Performed once the sympathizer has shown himself to be a regular in the shrine house, it asserts the links uniting him with his American and Ghanaian pairs and

9 Most priests use their own houses as shrine houses. Their houses are typically divided into spaces used for habitation and spaces dedicated to the worship of the deities and the organization of the rituals. Most houses have a meeting place where the practitioners are welcomed before entering the shrine room and where the various classes for the training of the priests are held. The altars for the deities are generally assembled in one or two shrine rooms. In most cases, a bigger room contains the shrines for the deities and a smaller space is dedicated to the worship of the ancestors. Practitioners are required to have altars and representations for their ancestors in their homes and, if initiated, to keep, at the very minimum, a shrine for the deity under which they were trained.

10 The practice of naming ceremonies can be found in many African American religious/political movements. In the 1930s, the name became the first sign of membership into the Nation of Islam. At that time, X and muslim names, such as Akbar or Muhammad, were offered to the practitioner who then abandonned the slave name he had inherited from the slave master.

11 In the shrine houses that I interracted with, the word "family" was frequently used to describe the members' relationship with their, above all, godmother, Nana Oparebea. 
more precisely with the officiants of the Akonedi shrine. “The tree is Larteh”, as I have been told many times in the field.

Lastly, the American Akan is given the ahene, a set of necklaces and bracelets to wear during rituals and ceremonies, which symbolize the different deities revered at the Akonedi shrine and its American branches. The practitioner is required to learn about the abosom, in particular about the one in the altars of his godmother or godfather's shrine room. He must familiarize himself with their songs and dance steps and must be capable of recognizing them during a ceremony. Later, if the new Akan becomes possessed $^{12}$ by one or a few deities, he will be required to undergo three years of training in order to lead him to the practice of the priesthood. During this training, he will learn how to perform the rituals and how to properly "possess" the abosom.

As a priest, the American Akan okomfo dedicates his life to the worship of the deities. He is aware of the significant shift in his life since joining the movement and becoming an officiant and accepts a life style often very different from the one to which he was once accustomed. Often times, American Akan describe their participation in the activities of a shrine house as a process of "healing”, which has enabled them to live freely and with the respect of their communities. Becoming Akan, in their view, therefore provides a path toward righteousness; a path that they follow thanks to the guidance of what is sometimes called the "Voices of Africa".

\section{Being Akan and Pan-African}

Once established in the United States, the Akan movement was forced to adapt and become more appealing and applicable to the numerous religious denominations present within the African American community. Indeed, the African American neighborhoods of the United States were then home to a variety of Christian churches, Muslim temples frequently led by the Nation of Islam and "African" shrine houses, such as Harlem's Yoruba Temple. The Akan movement, finally incorporated into that "religious field" ${ }^{13}$, reacted negatively to the spread of both Christianity and Islam and at once attempted to ensconce itself alongside the Yoruba religion.

Akan practitioners and the creator of the movement himself strongly believed that Christianity deserved to be condemned for its involvement in the enslavement of Africans. According to Dinizulu and, in fact, to most of the African American nationalist activists, the slaves who had converted to Christianity had been forced to do so by their slave masters and had thereby been driven against their will to disregard and forget their ancestral beliefs and practices. As a result, Dinizulu held that Christianity symbolized the power of the White man and was the enemy of the Akan practitioners, who had precisely to abandon their Christian faiths in order to reconnect with their African identities and religion.

12 The American Akan use the verb “to possess” in many manners. Sometimes, it is said that the deities are possessing the practitioners or are possessing on them. At other times, the group members would claim that they were possessed by or with an obosom. Last, it is very common to hear that it is the practitioner who possesses the god. A person who is capable of having that type of connection with the god will simply refer to his or her gift with the sentence "I possess".

13 The concept of "religious field" was introduced by Pierre Bourdieu. For a long and rich definition of this expression, see [16]. 
Like Christianity, Islam, too, was condemned by the movement's pioneers. Advocated in the 1960s mostly by the Nation of Islam, the religion was accused of being un-African and contrary to the very nature of Black people. The Nation of Islam, established in the 1930s by Master Fard Muhammad, asserted that African Americans should search for their origins not specifically in Africa, but rather within a group of chosen people often referred to as the Afro-Asiatic Tribe of Shabazz [17], who, together with Allah, created the first and greatest civilizations of the world. According to the American Akan, however, the attempt to disassociate African Americans from their Mother Land was extremely problematic, for it compelled the Black man to live a life which was greatly removed from what, according to the movement, was his original identity and his cultural and biological determinisms.

However, a number of the Akan practitioners were once regular members of the Nation of Islam. Nana Baakan Agyiriwah, for example, who was one of my closest contacts when I was conducting the research, left the Baptist and the Catholic churches that she frequented when she was a child for the Nation of Islam upon enrolling in college. Soon after, she began participating in a Sunni Muslim group and, then, in the Kemetic organization, Ausar Auset, before finally transitioning to the Yoruba and ultimately to the Akan religion. She received the rituals imposed on new members in each of these groups and had her name changed twice, from Cybil Fecha, the name she was given at birth, to Anesaah Rasheed, the name she acquired upon integration into the Nation of Islam, and, finally, to Nana Baakan Agyiriwah, the name she acquired upon claiming her Akan identity.

Like many other practitioners, Nana Baakan regarded her spiritual path from Christianity to the Akan religion as a logical evolution that gave her a better understanding of her identity as a woman of African descent in the U.S. She renounced her involvement with the Nation of Islam and considered her participation in the Yoruba and the Akan movement as a unique and self-fulfilling stage of her personal evolution. Her shrine house in Philadelphia contained shrines belonging to both the Akan tradition and to the Yoruba, and it was in front of both of these altars that she prayed, poured libation and performed readings. The first altar that a visitor saw when entering Nana Baakan's house was dedicated to the Yoruba orisha, Eshu. The altar was given to her by her Yoruba godfather and was central to the performance of many rituals. It was also that shrine that Nana sought when, traveling to another city, she prayed for her trip to be safe.

Nana Baakan's story is hardly an exception. Many of the priests that I met had been initiated into both the Yoruba and the Akan religions. It was not uncommon to find Yoruba priests waiting to begin their training in the Akan tradition or Akan akomfo regularly frequenting Yoruba shrine houses. The two groups often criticized one another and spread negative gossip; however, the practitioners involved with both did not recognize one affiliation as being dominant over the other. Thus, in their view, the Akan and the Yoruba religions coexist equally in the United States, and it is in their collaboration that they become the most efficient.

The Philadelphia shrine house conducted by Nana Baakan, the Adade Kofi Bosomfie Sankofa, regularly welcomed two women from Baltimore who were both initiated in the Yoruba priesthood. While I was conducting my research, the women were invited to each of the rituals that took place in the house, and they took part in them just as would other members. They were sometimes referred to by their Yoruba names, Sangotola and Ogunfumilayo, other times by their Akan names, Akua and Ama. Both received their ahene, necklaces and bracelets, and they wear them along with their Yoruba 
elekés $^{14}$. In February, 2005, Akua, began her training in the priesthood. Upon its completion, she described herself as both a Yoruba priest of the orisha Shangó and as an Akan okomfo of the obosom Nana Esi. According to these women, their participation in the two religions was due to the fact that the same logic pervades in both. They were guided by their ancestors and believed that dual practice was the only way that they can satisfy all of their deceased elders, Nigerians, as well as Ghanaians.

Closely connected with the two religions, the African American members of the Adade Kofi Bosomfie Sankofa created a series of equivalences between the two systems that applied to both the rituals and the characterization of their deities. The Akan religion as practiced in the United States, for example, centers on the reverence of the abosom, a large number of deities who receive, three days a week (shrine days), various offerings and libations. In their own shrine house, Sangotola and Ogunfumilayo chose to apply the Akan pattern of shrine days to the rituals they performed for their Yoruba orisha. Each of their altars, those consecrated to Eshú, Ogún, Oyá, Oshún, Yemayá and Shangó, as well as those for the abosom, Adade Kofi and Nana Esi, were pleased on shrine days, during which they received libations of gin, the favorite drink of the Akan gods, and prayers in a mixture of English, Twi and Yoruba.

The large majority of equivalences, however, were applied to the deities. If the "abosom and the orisha work together”, as one is often reminded by Akan practitioners, it is because each orisha finds an equivalent within the American Akan tradition. As a result, Asuo Gyebi, a main Akan deity, is often compared to Shangó, a Yoruba deity who shares Asuo Gyebi’s arrogance and thunder. Likewise, Ogún is frequently described as a Yoruba version of Adade Kofi, the "Akan" god of iron. Furthermore, Tegare, a deity of northern Ghanaian origination, is undergoing a process of "Yorubaization".

At the Akonedi shrine of Larteh Kubease, Tegare was commonly known as one of the children of Akonedi. As a suman ${ }^{15}$, he is the major element of an anti-witchcraft movement that emerged from the north of the country during the colonial era and that was incorporated within the practices of the Akonedi Shrine [19]. In Ghana, Tegare's northern origins are known to the practitioners who analyze his presence as a part of the syncretic nature of their religion. In the United States however, the role of Tegare is not that of a soldier battling against the use of witchcraft. If some practitioners are aware that his worship originated in the northern part of Ghana, they nevertheless consider him as a major component of what is labeled the "Akan” religion. Among the Akan shrine houses in the United States, Tegare's attributions are then redefined, transforming the deity into a type of messenger between the abosom and the practitioners. In everyday worship, Tegare is the first entity consulted by the priests. During a practitioner's life and religious path, that same entity is often the first presence that is felt, the first that causes a state of semi-possession. Tegare is a "gate opener" as one is often reminded during rituals, the first connection, the "facilitator".

14 The word elekés refers to the necklaces that are given to the practitioner in the Yoruba tradition. The ceremony of the elekés usually opens the spiritual career of the believer.

15 The word suman is used by the Akan of Ghana to talk about a spiritual entity that was built by an officiant and fixed inside of an object, very often a "talisman" or a piece of fabric tied on the believer's leg or arm. Called amwan in the Ivory Coast, the suman is inherited inside of the matrilineage and always lies on a set of taboos imposed on his carrier. About that concept of suman, see [18]. 
In the Yoruba religion, this messenger function is carried out by the deity Eshú. It is the one deity that opens the ceremonies and that the practitioners have to go to before they can interact with the others. Transferred into America, Tegare has then become an Akan version of the Yoruba Eshú. Tegare and Eshú, referred to as the two tricksters in most Akan shrine houses ${ }^{16}$, usually received their offerings together on a shared altar commonly located at the houses' entries. While I was conducting the research, many Akan priests insisted that while at home they could distinctly hear the two deities chatting amongst themselves, joking with each other and begging for such offerings as peanuts, rum and candies ${ }^{17}$. By making these assertions, the priests were claiming to be the chosen witnesses of the connections between two African deities that they believed were equivalents and carriers of one singular energy.

In the North American context, within the American Akan shrine houses, one can therefore observe the creation of a new type of syncretism. This creation is not linked to the diffusion process of Ghanaian beliefs and entities per se, but to the production inside of the U.S.'s religious field of new practices. Indeed, if links are created between Yoruba and Akan practices in the United States, it is not because in Africa, such connections could be made, but because in that specific context, these two religions have been appropriated among groups of African American cultural nationalists who attempt to search for their roots. In truth, in the United States, the members of both the Akan and Yoruba movements have developed what they believe is and qualifies as a new and unique "Pan-African religion”. Where the process of re-Africanization in the United States, as it was led by Oseijeman Adefunmi, was born out of an effort to resist the syncretic aspect of Cuban Santería, the process today has arrived at a new phase that demands the "resyncretization" of the two systems of belief, which are deemed to be genuinely African. Unlike the Cuban slaves who hid their African deities behind Catholic saints, the practitioners of the Akan and Yoruba religions today deliberately combine various spiritual entities originating from different parts of Africa. In doing so, they have developed a North American "African” tradition that distinguishes them both from their Caribbean peers and from the Africans themselves, who they sometimes dismiss as having been corrupted by centuries of colonialism.

Creating this Pan-African religion, the Akan and Yoruba practitioners often held that their system of beliefs was inherited from a pre-colonial ancestral Africa, which was culturally united, then destroyed and forgotten, and has today been "reterritorialized" in the United States. ${ }^{18}$. In that regard, they present an imaginary construct of Africa whose presumably "authentic" form is thought of as unchanged, untouched by colonialism and recreated in the Americas. They do not deny the existence of syncretism in Africa, but they maintain that their own North American creation is enhancing what they think of as the pre-colonial essence of the Motherland. In that sense, the transnationalization of the Akan religion

16 Usually used to describe Eshú's behavior, the word trickster is now equally applied to Tegare.

17 Apart from the libations, which are learned by the practitioners during their initiation to the priesthood and pronounced in Twi, conversations during rituals are always held in English. In the case of discussions between Tegare and Eshu, the priests usually claim to hear them speaking in English. When they try to reproduce their words, they then adopt what they refer to as “ an African accent” influenced by their experiences in Africa or in the West African neighborhoods of North American cities.

18 Ideas of a pre-colonial culturally united Africa are very common within African American nationalists groups. They are also present in the writtings of many afrocentrist scholars inspired by Cheikh Anta Diop's seminal book L'unité culturelle de l'Afrique noire [19]. 
that they participate in is thought of as an ongoing process, where the modification of the ritual can lead to the creation of an even more "authentic" tradition. If reproducing Akan rituals was allowing them to reconnect with their Ghanaian ancestries, bridging the gap between Yoruba and Akan practices can help them recreate, spiritually and within the United States, a Pan-African Africa that existed before the continent's contact with Europeans.

\section{Being Akan, Pan-African and African American}

Deities and rituals are crucial in the making of the Akan identity in the United States. Maintaining, in rituals, relationships with other African deities, the abosom become incarnate proof of the Pan-African side of Akan identity. This Pan-African side connects Akan practitioners to an "original” Africa, grasped in its pre-colonial form. However, only rarely worshiped alone, these deities are also associated with other entities, which are turning the Akan religion, as it is practiced in the United States, into a truly African American spirituality. Associated with the ancestors, the orisha and the abosom constitute a wide range of spiritual entities requiring common rituals that will allow the American Akan to include their own history and experience in their effort to reach their African roots.

In each Akan shrine house, one can find series of altars devoted to the worship of the ancestors. Placed on high tables, they consist of photographs, trinkets and souvenirs and are often covered with drapes. Colorful and crowded, they contrast sharply with the altars dedicated to the abosom, which are located on the floor and made only of a terracotta pot and a small wooden doll. In Nana Baakan's shrine house in Philadelphia, altars to ancestors were separated from those of Ghanaian deities by a curtain.

We now know that when Nana Oparebea taught her American followers some elements of Akan religious traditions, she did not share with them the knowledge, symbols and tools that would have enabled them to implement the worship of ancestors in the New World similar to the one encountered in Larteh. In Larteh Kubease, ancestor worship is under the responsibility of the political authority of the city, the Kubeasehene. It is he who, during such rituals as the Akwasidae, sheds the blood of the sacrifices on a set of blackened stools symbolizing the power of the lineages' ancestors. In the United States, although Dinizulu was honored with the title of "Chief of the Akan in America”, almost none of the shrine houses present in the country host a blackened stool, which would have permitted the perpetrating of the Ghanaian rituals. Therefore, in the United States, the Akan ancestor worship has been disassociated from its Ghanaian heritage. It became a laboratory of religious innovation, where African American practitioners were able to create a third space of worship interacting with the ones inhabited by the abosom and the orisha.

There are two main kinds of ancestors represented on altars. In Nana Baakan's shrine house, there was, first, a high table on which were represented the priestess' closest family, her parents, grandparents and great-grandparents. She considered this altar as being her personal section of the shrine house and was never possessed during the rituals by any of the entities that it contained. The second altar was located to the left of the first. A table covered with purple and white sheets, this altar was made of a porcelain bowl, a wooden sculpture depicting the ankh (the Egyptian symbol of the key of life), several bottles of Southern Comfort liqueur, a pipe and two carved wooden canes. Above the altar were a violet cotton dress and a rocking chair from which a straw hat was hanging. 
Nana Baakan explained that this second altar was dedicated to a set of entities that visited her during her sleep and asked her to devote a sacred space to them in her shrine house. Among these ancestors, Nana Baakan took care of a group of African American personalities, including Martha, a woman who gradually revealed to the priestess her entire personal history. According to Nana Baakan, Martha was from Ghana. In the 19th century, she was made a slave and transported to Brazil. Then, she was moved again to South Carolina, where she worked on one of the state's largest plantations. She was the master's favorite, and he abused her on many occasions. She gave birth to ten of his children. One day, one of Martha's grand-daughters resisted the assault of the slave owner. Outraged, he took his revenge on Martha by putting out her eyes. For several long years afterward, Martha lived, blind, on the plantation. It is said that not being able to see, she became a strong medium. One day, her grand-daughter was able to kill the slave owner and helped Martha escape up North.

When mentioning Martha, Nana Baakan always spoke with enthusiasm, multiplying details and information on the life of this woman she admired. Martha was also one of the shrine house members' favorite entities. While I was conducting my research, many Akan practitioners told me their memories of some of the conversations they had with Martha during rituals, when she possessed Nana Baakan. For them, Martha's discourses and advice were fascinating. They always wanted to learn more about her, and Nana Baakan had made them a set of documents they could use in their search, including a few tapes recorded during some of the rituals during which she appeared.

If Martha was so popular in Nana Baakan's shrine house, it is probably because in the discourse produced on her past life, she was a victim of slavery. In a way, it is a major part of the African American experience, the painful past of the community, as well as its resistance to oppression that Martha personified. The story of her life, as Nana Baakan told it, assembled most of the stereotypes widely associated with slave life in the African American representations. According to Baakan, Martha was a house slave. She had a special status within the plantation, which sometimes created conflict between her and the other slaves. Perpetually raped by the master, she had given birth to mixed-race offspring, of whose pale complexion she was ashamed. At night, when trying to escape the life of the plantation, Martha sat on the steps of her master's colonial house on a rocking chair, identical to the one Nana Baakan placed next to her altar. Wearing her straw hat, the Bible on her lap, she was humming spirituals and praying for the emancipation of her people.

This vision of Martha that Nana Baakan cherished and imposed on her altar, alone, singing spirituals on her rocking chair is a real iconic picture of life in the South before the Civil War. For the members of the shrine house, Martha was an iconic figure, a heroine who, in the greatest pain, waited for the decay of her master through her prayers and hoped for the emancipation of her community. Thus, she had become the perfect embodiment of a set of African American enslaved ancestors, whose descendants often have no clear genealogy for and, next to the African deities, have decided to venerate. As a unifying ancestor in the shrine house, Martha represented the memory of every members' great-grandparents and great-great-grandparents and gave them an opportunity to honor their accomplishments and their heritage.

Along with Martha, there were other ancestors in the shrine house that represented this memory of slavery. Ephraim, one of the shrine members, described to me one of the ancestors he felt particularly close with: Mary. This entity, he said, often visited him in his dreams and also possessed him during the rituals. According to Ephraim, Mary was originally from Togo. At the age of 15, she was deported 
to Louisiana to work on a plantation. Ephraim recognized that Mary carried a spiritual force during the possession that sometimes was hard for him to handle. As if all of her anger and the many uprisings she led in the plantation were still right here in her spirit. Nyo, another shrine member, was in regular contact with one of her personal ancestors named Zafina. Born in the Gold Coast, Zafina never left Africa. However, as a little girl, she witnessed the kidnapping of her entire family by the white man. Nyo often described this vision that she had in a dream that featured Zafina, hidden behind a dune on a beach, looking at her parents being forced on a boat leaving for the Americas.

In Nana Baakan's shrine and affiliated houses, during the rituals referred to as the ancestor parties, it was common for these specific entities to be embodied at the same time and to reminisce together about the tragic memories of their enslavement. Each house member knew how to recognize them and was familiar with their specific way of talking and their behaviors. In fact, everything happened as if these entities, exclusively African American, formed a sort of heritage shared by the group members.

By establishing ancestor worship in their house, the members of the group took into consciousness the traumatic experience of slavery as a foundation of African American History. Whereas they would not deny the importance of slavery within the history of Ghana, the slave trade they concentrate on in the worship is clearly bringing them back to their own North American heritage. When most of the nationalist groups of the twentieth century decided to downplay the role of slavery in African American history in order to prove the continuity of Black people's heritage between the Motherland and the diaspora, members of the Akan movement include slavery in their history. Therefore, there is no contradiction for them between a recovered African identity, being Akan or Pan-African, and an African American consciousness born out of separation and loss of cultural markers. On the contrary, their "African-Americanness" becomes parts of their "Africanness”, while during ceremonies, their enslaved ancestors are revered with the same ritual tools as the Akan deities: prayers in Twi language, libation and possession.

\section{Conclusions}

The diffusion of the Akan religion in the United States by way of transnational networks has been followed by what Arjun Appadurai [20] would call a process of indigenization. That process helped the religion integrate the complex reality of the African American religious field and adapt itself to the identity politics at stake. This indigenization process has led to the association of Akan deities with other African gods present in North America, the orisha mostly, and to the creation, inside of the ritual, of a unique space devoted specifically to their African American heritage. Therefore, while claiming to be members of a unique transnational community, members of the Akan movement still recognize their specific location within the context of global Pan-Africanism and within the United States.

In this paper, I have tried to show how the practitioners formed their identities around three main and intertwined lines. First, members of the group renounced their Black American identity in order to adopt a new one, Akan, thought of as identical to the one their ancestors carried before being enslaved in the Americas. In order to do so, they had to go through a set of rituals whose goals were both to purify their body and consciousness from White society and to help them reconnect with their African selves. This Akan identity, recreated in the United States, was then performed during ceremonies and especially during possession, when American Akan embodied the deities of Larteh. 
Second, members of the Akan movement aspired to be recognized as truly Pan-African. In their religious practice, they achieved this goal by being initiated in more than one African religion and by associating in their everyday practices deities from different belief systems. As both Yoruba and Akan, they saw themselves as the true representatives of what they considered as pre-colonial Africa, where the cultures of the continent were united, forming a unique essence, only destroyed when colonial rule created ethnic antagonisms. In their mind, to be Pan-African meant to be a true African, original and possibly "more authentic" than the current inhabitants of the Motherland. Therefore, it is interesting to note that it is precisely their own adaptation or even Americanization of the religion practiced in Larteh that they claim as being the most authentic. In their ritual practices and beliefs, the discourse of authenticity produced by North American Akan practitioners is then precisely informed by the mutations and changes they ideologically want to condemn.

Finally, the American Akan were describing themselves as the representatives of an African American experience. This African American experience and heritage differentiated them from Africans from the continent, as well as from other members of the Black diaspora. Therefore, the African American consciousness that one had to renounce when becoming Akan became the focus point of an alternate identity formation. In the Akan ritual, it was the ancestor worship that raised this third identity dynamics. Along with the abosom and the orisha, the ancestors were bringing another dimension to the rituals, adding complexity to the nature of the heritage that it revered.

The history of the Akan movement is a constant negotiation between these three lines. As always, when it comes to identity processes, according to the circumstances, members of the group would describe themselves as Akan, Pan-African or African American, and sometimes all three at the same time. In the search for a past, for a memory that would allow them to appropriate all of the different aspects of their history, African American Akan are creating a multiple identity based on a logics that could be described following Jean-Loup Amselle's notion of “branchements” (plugging) [21]. In order to exist freely and to resist the difficulties of identity and racial formations, members of the Akan movement decided to "plug" themselves into different pasts: an Akan heritage, the history of an independent Ghana, a Pan-African and recreated pre-colonial past, as well as their own history in the United States grounded in the tragedy of slavery. In these logics, rituals become absolutely central, as they provide coherence and integrity to long-term segmented histories and identities.

\section{Conflicts of interest}

The author declares no conflicts of interest.

\section{References}

1. James H. Meriwether. Proudly We can Be African. Black Americans and Africa, 1935-1961. Chapel Hill and London: University of North Carolina Press, 2002.

2. E.U. Essien Udom. Black Nationalism: A Search for Identity in America. New York: Dell, Publishing, 1964.

3. Stokely Carmichael, and Charles V. Hamilton. Black Power. The Politics of Liberation. New York: Vintage, 1967.

4. Maulana Karenga. Introduction to Black Studies. Los Angeles: University of Sankore Press, 1993. 
5. George Brandon. Santeria from Africa to the New World. The Dead Sell Memories. Indiannapolis: Indiana University Press, 1999.

6. Stefania Capone. Les Yoruba du Nouveau Monde. Religion, Ethnicité et Nationalisme noir aux États-Unis. Paris: Karthala, 2005.

7. Kamari Clarke. Mapping Yoruba Networks. Power and Agency in the Making of Transnational Communities. Durham and London: Duke University Press, 2004.

8. Pauline Guedj. Panafricanisme, Religion Akan et Dynamiques Identiraires aux Etats-Unis. Le Chemin du Sankofa. Paris: L'Harmattan Connaissance des Hommes, 2011.

9. Stefania Capone. La Quête de L’Afrique Dans le Candomblé. Pouvoir et Tradition au Brésil. Paris: Karthala, 1999.

10. Alejandro Frigerio. "Reafricanization in Secondary Religious Diasporas: Constructing a World Religion.” Civilisations 51 (2004): 39-60.

11. Steven Gregory. Santeria in New York City. A Study in Cultural Resistance (Study on African-American History and Culture). New York: Garland Publishing, 1999.

12. Pauline Guedj. “Diaspora: Re-Africanization.” In New Encyclopedia of Africa. Edited by John Middleton. Boston: Gale Publishing, 2007, p. 890.

13. Stephan Palmié. “Against Syncretism: 'Africanizing' and 'Cubanizing' Discourses in North American Orisà Worship.” In Counterworks: Managing the Diversity of Knowledge. Edited by Richard Fardon. London: Routledge, 1995, pp. 73-104.

14. E. Evans-Anfom. Traditional Medicine in Ghana: Practices, Problems and Prospects. Accra: J.B. Danquah Memorial Lectures, 1986.

15. David Brokensha. Social Change at Larteh, Ghana. Oxford: Clarendon Press, 1966.

16. Pierre Bourdieu. "Genèse et Structure du Champ Religieux.” Revue Française de Sociologie 12 (1971): 295-334.

17. Elijah Muhammad. Message to the Black Man in America. Chicago: Mosque of Islam, 1965.

18. Véronique Duchesne, and Pauline Guedj. “Akonedi ne Voyage pas. La Formation d'un Réseau Transnational Akan Entre le Ghana et les Etats-Unis.” In Entreprises Religieuses Transnationales en Afrique de l'Ouest. Edited by Laurent Fourchard, André Mary and René Otayek. Paris and Ibadan: Ifra-Karthala, 2005, pp. 135-53.

19. T.C. McCaskie. “Anti-Witchcraft Cults in Asante.” History in Africa 8 (1981): 125-54.

20. Cheikh Anta Diop. L'unité Culturelle de l'Afrique Noire. Paris: Présence Africaine, 1959.

21. Arjun Appadurai. “Modernity at Large.” In Cultural Dimensions of Globalization. Saint Paul: University of Minnesota Press, 1996.

22. Jean-Loup Amselle. Branchements: Anthropologie de L'universalité des Cultures. Paris: Flammarion, 2001.

(C) 2015 by the author; licensee MDPI, Basel, Switzerland. This article is an open access article distributed under the terms and conditions of the Creative Commons Attribution license (http://creativecommons.org/licenses/by/4.0/). 